Research Paper

\title{
Identification of pathogens and virulence profile of Rhodococcus equi and Escherichia coli strains obtained from sand of parks
}

\author{
M.C. Fernandes ${ }^{1}$, S. Takai ${ }^{2}$, D.S. Leite ${ }^{3}$, J.P.A.N. Pinto ${ }^{1}$, P.E. Brandão ${ }^{4}$, V.A. \\ Santarém $^{5}$, F.J.P. Listoni ${ }^{1}$, A.V. Da Silva ${ }^{6}$, M.G. Ribeiro ${ }^{1}$ \\ ${ }^{1}$ Departamento de Higiene Veterinária e Saúde Pública, Faculdade de Medicina Veterinária e Zootecnia, \\ Universidade Estadual "Júlio de Mesquita Filho", Botucatu, SP, Brazil. \\ ${ }^{2}$ Department of Animal Hygiene, School of Veterinary Medicine and Animal Sciences, \\ Kitasato University, Japan. \\ ${ }^{3}$ Departamento de Genética, Evolução e Bioagentes, Instituo de Biologia, \\ Universidade Estadual de Campinas, Campinas, SP, Brazil. \\ ${ }^{4}$ Departamento de Medicina Veterinária Preventiva e Saúde Animal, \\ Universidade de São Paulo, São Paulo, SP, Brazil. \\ ${ }^{5}$ Curso de Medicina Veterinária, Universidade do Oeste Paulista, Presidente Prudente, SP, Brazil. \\ ${ }^{6}$ Departamento de Ciências Biológicas, Universidade Estadual de Feira de Santana, Bahia, Brazil.
}

Submitted: March 19, 2011; Approved: September 10, 2012.

\begin{abstract}
The identification of pathogens of viral (Rotavirus, Coronavirus), parasitic (Toxocara spp.) and bacterial (Escherichia coli, Salmonella spp., Rhodococcus equi) origin shed in feces, and the virulence profile of $R$. equi and E. coli isolates were investigated in 200 samples of sand obtained from 40 parks, located in central region of state of Sao Paulo, Brazil, using different diagnostic methods. From 200 samples analyzed, 23 (11.5\%) strains of $R$. equi were isolated. None of the $R$. equi isolates showed a virulent (vapA gene) or intermediately virulent (vapB gene) profiles. Sixty-three (31.5\%) strains of $E$. coli were identified. The following genes encoding virulence factors were identified in E. coli: eae, bfp, saa, iucD, papGI, sfa and hly. Phylogenetic classification showed that 63 E. coli isolates belonged to groups B1 (52.4\%), A (25.4\%) and B2 (22.2\%). No E. coli serotype O157:H7 was identified. Eggs of Toxocara sp. were found in three parks and genetic material of bovine Coronavirus was identified in one sample of one park. No Salmonella spp. and Rotavirus isolates were identified in the samples of sand. The presence of $R$. equi, Toxocara $\mathrm{sp}$, bovine Coronavirus and virulent $\mathrm{E}$. coli isolates in the environment of parks indicates that the sanitary conditions of the sand should be improved in order to reduce the risks of fecal transmission of pathogens of zoonotic potential to humans in these places.
\end{abstract}

Key words: enteric pathogens, virulence, sand, feces, parks, E. coli, R. equi.

\section{Introduction}

Enteric pathogens are a major group of organisms related to infections in humans and animals. These pathogens are resistant to adverse environmental conditions and are frequently transmitted by oral route due to fecal contamina- tion of foods, water, vegetables and fruits (Acha and Szyfres, 2003).

Sandboxes are commonly found in parks all over the world, and are mainly used by children and adolescents. Access of companion animals, birds and occasionally livestock, inadequate hygiene of the sandboxes, precarious hygiene habits of children, and lack of knowledge about the

Send correspondence to M.G. Ribeiro. Disciplina de Doenças Infecciosas dos Animais Domésticos, Departamento de Higiene Veterinária e Saúde Pública, Faculdade de Medicina Veterinária e Zootecnia, Universidade Estadual Paulista "Julio de Mesquita Filho", Caixa Postal 560, 18618-970 Botucatu, SP, Brazil. E-mail: mgribeiro@fmvz.unesp.br. 
risks posed by microorganisms eliminated in feces of animals favor the transmission of pathogens of animal origin to humans in these places (Matsuo and Nakashio, 2005).

The present study investigated the presence of pathogens of viral (Coronavirus, Rotavirus), parasitic (Toxocara spp.) and bacterial (E. coli, Salmonella spp., R. equi) origin eliminated in feces of animals, and the virulence profile of $R$. equi and $E$. coli isolates, obtained from the sand of parks located in the central region of state of Sao Paulo, Brazil.

\section{Materials and Methods}

\section{Collection of samples}

Two hundred samples of sand from 40 parks were analyzed. The strains were collected between 2008 and 2009. All parks were located in the central region of state of Sao Paulo, Brazil. After superficial dirt was removed, about $250 \mathrm{~g}$ of soil were collected 10-15 cm deep. Samples were placed in individual plastic bags and taken to laboratory under refrigeration $\left(4-8^{\circ} \mathrm{C}\right)$.

\section{Culture, identification and storage of bacterial isolates}

All samples were processed in the Laboratory of Microbiology and Infectious Diseases of Animals, Department of Veterinary Hygiene and Public Health, School of Veterinary Medicine, UNESP - Universidade Estadual Paulista, Botucatu, Sao Paulo, Brazil. Samples were kept under refrigeration $\left(4-8{ }^{\circ} \mathrm{C}\right)$ or frozen $\left(-20^{\circ} \mathrm{C}\right)$ until they were analyzed.

Samples (25 g) of feces from all parks were inoculated aseptically in $225 \mathrm{~mL}$ sterilized distilled water. After homogenization, $0.03 \mu \mathrm{L}$ of material was inoculated in defibrinated bovine blood agar (5\%) and MacConkey agar for $E$. coli isolation. Plates were incubated at $37^{\circ} \mathrm{C}$ for three days and were assessed every day for bacterial growth. Simultaneously, $0.03 \mu \mathrm{L}$ of these samples were cultured in NANAT selective media for $R$. equi (Takai et al., 1996). Microorganisms were identified by colony morphology, staining methods, and biochemical tests (Quinn et al., 1994). Isolates of bacterial origin were stored in Lignièris agar at $25^{\circ} \mathrm{C}$.

\section{Identification of Salmonella spp.}

Briefly, samples (25 g each) were inoculated into $250 \mathrm{~mL}$ of peptone water $1.0 \%$ (Oxoid) and incubated at $35^{\circ} \mathrm{C}$ for $24 \mathrm{~h}$. Aliquots of $0.1 \mathrm{~mL}$ and $1 \mathrm{~mL}$ were inoculated each into $10 \mathrm{~mL}$ of Rappaport-Vassiliadis (RV) (Oxoid) and Tetrathionate (TT) (Oxoid) broth, respectively, and incubated at $42^{\circ} \mathrm{C}(\mathrm{RV})$ and $35^{\circ} \mathrm{C}(\mathrm{TT})$ for $24 \mathrm{~h}$. A loopful of each broth culture was inoculated simultaneously in xylose-lysine-desoxycholate agar (XLD) (Oxoid) and bismuth sulfite agar (BS) (Oxoid), followed by incubation at $35^{\circ} \mathrm{C}$ for $24 \mathrm{~h}$. Colonies suggestive of Salmonella were inoculated in triple sugar iron (TSI) and lysine iron (LIA) agar slants. Tubes were incubated for $35^{\circ} \mathrm{C}$ for $24 \mathrm{~h}$. Colonies suggestive of Salmonella spp. in at least one of the culture media (TSI or LIA) were submitted to biochemical tests, agglutination test using polyvalent anti-Salmonella serum (Probac) (Quinn et al., 1994; Andrews et al., 1998), and serotype identification(Popoff and Le Minor, 1992).

\section{Virulence of $R$. equi}

Isolation of plasmid DNA was obtained by using an alkalin lysis method (Takai et al., 2003). Target DNA for PCR amplification was based on the genes encoding a 15-17 kDa antigen (vapA gene), and a $20 \mathrm{kDa}$ antigen (vapB gene) sequence. Plasmid DNA was digested with restriction endonucleases (EcoRI, EcoT22I and HinddIII). Primer 1 (5'-GACTCTTCACAAGACGGT-3') and primer 2 (5'-TAGGCGTTGTGCCAGCTA-3') were used to detect virulent (vapA gene) strains and the 569-552 bp expected product. Primer 3 (5'-AACGTAGTCGCGGTGAG AA-3') and primer 4 (5'-ACCGAGACTTGAGCGACTA$\left.-3^{\prime}\right)$ were used for intermediately virulent (vapB gene) isolates to detect the 1066-1048 bp expected product. Samples were submitted to 30 cycles of amplification as follows: denaturation for $90 \mathrm{~s}$ at $94{ }^{\circ} \mathrm{C}$, annealing for $1 \mathrm{~min}$ at $55^{\circ} \mathrm{C}$, and extension for $2 \mathrm{~min}$ at $72{ }^{\circ} \mathrm{C}$ (Takai et al., 1996; Takai et al., 2003). Characterization of plasmid virulence was performed in Kitasato University, Japan.

\section{E. coli serotypes and virulence factors}

Sorbitol-negative O157:H7 serotypes were submitted to agglutination test with $\mathrm{O} 157$ and $\mathrm{H} 7$ sera (Probac). Reference strains were E. coli FVL2 (sfa, pap, iucD, hly, cnf-1), FV35 (afa, iucD, cnf-1), J96 (papGII, papGIII), O157:H7 (vt1, vt2, eae), 2348/69 (eae, bfp, eaf), IANO (stb, 1t1), EAEC O42 (eaec), B90 (cnf-2), FVL16 (cnf-1, hly, pap, sfa, iucD), ETEC13 (sta), EIEC (ipaH), supplied by the Laboratory of Bacterial Antigens, Campinas State University, Brazil. E. coli DH5 $\alpha$ strain was used as a negative control. First, primers for virulence factor genes were determined individually using a template DNA from appropriate positive and negative control strains. The presence of the following groups of genes were analyzed by PCR: $p a p C$ and $p a p G$ alleles (P fimbria), $s f a C / D$ (S fimbria), $a f a B / C$ (afimbrial adhesin), saa (self-agglutinating adhesin), iucD (aerobactin), $c n f-1$ and $c n f-2$ (cytotoxic necrotizing factor type 1 and 2), hly ( $\alpha$-hemolysin), vtl and $v t 2$ (verotoxins), sta and $s t b$ (heat stable toxins), lt1 (heat labile toxins), eaec (E. coli EAEC), ipaH (E. coli EIEC), and eae, eaf and bfp (E. coli EPEC). Appropriate primer sequences, annealing temperature, and size of amplified fragment (base pairs bp) for these genes were determined in previous studies (Schmidt et al., 1995; Yamamoto et al., 1995; Blanco et al., 1996; Blanco et al., 1997; Karkkainen et al., 1998; Aranda et al., 2004; Villareal et al., 2006). Phylogenetic classifica- 
tion (chuA, yjaA, TspE4.C2) in groups A, B1, B2 and D was performed by PCR (Emödy et al., 2003).

\section{Identification of Toxocara spp.}

Flotation-centrifugation with sodium nitrate $\left(\mathrm{Na}_{2} \mathrm{NO}_{3}\right) 1.20 \mathrm{~g} / \mathrm{cm}^{3}$ was used for the recovery of Toxocara spp. eggs. Centrifugation was performed at $2.500 \mathrm{rpm}(679 \mathrm{~g})$ for $5 \mathrm{~min}$. After that, the supernatant of each tube was placed in microscope slides, covered with coverslips, and examined under a light microscope (10x). This process was repeated three times for each sample (Santarém et al., 1998).

\section{Diagnosis of bovine coronavirus (BCoV)}

Samples were tested for the presence of $\mathrm{BCoV}$ with a group II coronavirus specific RT-PCR assay targeted to the RNA-dependent RNA-polymerase gene (RdRp) with a 136-bp predicted product (Brandão et al., 2005). BCoV Kakegawa strain (Akashi et al., 1980) and PBS were used as positive and negative controls, respectively.

\section{Diagnosis of rotavirus}

Samples were analyzed for the presence of rotavirus 11-segment RNA using polyacrylamide gel electrophoresis-PAGE (Herring et al., 1982). NCDV group A rotavirus strain was used as the positive control.

\section{Statistical analysis}

Chi-square test (Epi-Info, 6.4) was used to evaluate the differences in the presence of different pathogens in the parks, considering $\mathrm{p}<0.05$ (Triola, 2005).

\section{Results}

The frequency of pathogens identified in samples of sand obtained from parks is shown in Table 1. There was no statistical difference $(p>0.05)$ between the presence of the different pathogens in the parks sampled.

$E$. coli and $R$. equi strains were the most common pathogens isolated throughout the study. $R$. equi strains were isolated in $23(11.5 \%)$ sand samples. None of the $R$. equi isolates showed virulent (vapA gene) or intermediately

Table 1 - Identification of pathogens from fecal origin in sand of parks. Brazil, 2010

\begin{tabular}{lcc}
\hline Pathogens & Frequency & p value \\
\cline { 2 - 2 } & $\begin{array}{c}\text { Isolates identified / total of } \\
\text { specimens (\%) }\end{array}$ & \\
\hline Escherichia coli & $23 / 200(11.5)$ & 0.33 \\
Rhodococcus equi & $63 / 200(31.5)$ & 0.27 \\
Toxocara spp. & $3 / 200(1.5)$ & 0.5 \\
bovine Coronavirus & $1 / 200(0.5)$ & 0.5 \\
\hline № = number. & \\
$\mathrm{p}<0.05$ indicates statistical differences between microorganisms.
\end{tabular}

virulent (vapB gene) plasmid profiles. Sixty-three (31.5\%) strains of $E$. coli were identified. The following virulence factor genes were identified in the E. coli strains: eae, $b f p$, saa, iucD, papGI, sfa and hly. Phylogenetic classification showed that the $63 \mathrm{E}$. coli isolates belonged to groups B1 (52.4\%), A (25.4\%) and B2 (22.2\%). No E. coli serotype O157:H7 was identified (Table 2).

Eggs of Toxocara spp. were recovered only in three of the parks.

Genetic material of bovine Coronavirus was identified in one public park (Table 1), as suggested by the sequencing analysis of the $136 \mathrm{bp}$ amplicon obtained in one sample (data not show). No Salmonella spp. or Rotavirus isolates were identified in the samples of sand.

\section{Discussion}

Rhodococcus equi is a well-recognized Gram positive intracellular bacterium associated with different clinical manifestations in humans and animals. The organism is widespread in soil, particularly in feces of foals, other herbivores and their environment (Prescott, 1991). The virulence mechanism of this pathogen is related with the presence of virulence-associated plasmids-Vap (Takai et al., 1991), and three levels of virulence are currently recognized: virulent, intermediately virulent and avirulent (Takai, 1997). Virulent $R$. equi strains contain a large plasmid of $85-90 \mathrm{~kb}$, responsible for encoding the $15-17-\mathrm{kDa}$ antigens (VapA) that are considered the major causes of suppurative pneumonia in foals (Ribeiro et al., 2005). VapB or intermediately virulent isolates present 20-kDa antigens and a 79-100 kb plasmid (Takai, 1997). They are frequently observed in swine lymphadenitis (Takai et al., 1996) and patients infected by acquired immunodeficiency syndrome-AIDS (Takai et al., 2003). In contrast, avirulent strains show no evidence of either vapA or vapB genes. These strains are found in the soil of areas where foals are raised, in soil and/or sand of human dwelling, mainly in yards and parks, and in humans with rhodococcosis co-infected by AIDS virus (Takai et al., 1996; Takai, 1997).

Table 2 - Phylogenetic classification and virulence factors of Escherichia coli strains isolated from sand samples of parks. Brazil, 2010.

\begin{tabular}{lcc}
\hline Phylogenetic classification & Gene & Number of strains \\
\hline A & saa & 6 \\
A & papGI, sfa, hly & 1 \\
B1 & saa & 3 \\
B1 & $e a e$ & 1 \\
B1 & $i u c D$ & 1 \\
B1 & $e a e, b f p$ & 1 \\
B1 & $s a a, e a e, b f p$ & 1 \\
B2 & saa & 2 \\
\hline
\end{tabular}


All our $R$. equi strains were classified as avirulent. These results are in agreement with similar study in Japan, which also reported the presence of avirulent $R$. equi in the soil of parks and yards (Takai et al., 1996). Avirulent strains have been frequently identified in the environment of domestic animals, particularly foals (Takai, 1997). Currently, $R$. equi has emerged as a pulmonary pathogen among immunosuppressed patients, mainly those infected by AIDS virus (Acha and Szyfres, 2003). A recent survey of $R$. equi virulence profile in 20 humans in Brazil showed 11 patients infected with avirulent strains (Ribeiro et al., 2011). Plasmid virulence of $R$. equi strains isolated in Brazil was characterized in foals (Ribeiro et al., 2005) and a $\operatorname{dog}$ (Farias et al., 2007). The present study was the first investigation in this country about virulence profile of $R$. equi strains isolated from park sand. Beside the absence of virulent or intermediately virulent $R$. equi strains, the presence of this microorganism in the sand of parks constitutes a public health problem. This risk is particularly important to children and immunocompromised people, especially HIV-positive patients, because avirulent $R$. equi may cause the disease in immunosuppressed and non-immunosuppressed patients (Takai et al., 2003), including in Brazil (Ribeiro et al., 2011).

E. coli is a very diverse species of bacteria found both in the intestinal tract of humans and animals, and in the environment. The microorganism is classified in six different pathotypes based on enteric manifestations, as follows: enterotoxigenic (ETEC), enteropathogenic (EPEC), enteroinvasive (EIEC), enterohemorrhagic (EHEC), enteroaggregative (EAEC), and diffusely adherent (DAEC). Pathogenic manifestations of $E$. coli are closely related with different virulence factors, including enterotoxins, cytotoxins, fimbriae, adhesins, and iron chelation mechanisms (Kaper et al., 2004).

Gene eae encodes intimin, which mediates the intimate attachment of EPEC and EHEC to epithelial cells, and stimulates mucosal immune response and intestinal crypt hyperplasia. Gene eae and $b f p$ were found in three strains isolated from the sand of parks in the present study, and are generally related with atypic enteropathogenic $E$. coli. This class of $E$. coli EPEC causes diarrhea in children younger one year of age, mainly in emerging countries (Kaper et al., 2004). In Brazil, there was a case of concurrent infection of a child and a dog by enteropathogenic $E$. coli that showed eae gene and was isolated from feces (Rodrigues et al., 2004). Atypic EPEC isolated from parks constitutes a public health risk, especially for children and immunosuppressed humans.

P fimbriae are known to contribute for E. coli pathogenesis by promoting colonization of host tissues and stimulating injurious inflammatory response in the host (Kuehn et al., 1994). PapG adhesin is located on $\mathrm{P}$ fimbria. Three classes of PapG (PapGI, PapGII and PapGIII) are recognized: papG Class I are predominantly found in fecal strains; allele GII in strains involved in pyelonephritis and bacteremia cases; and allele GIII in isolates responsible for cystitis cases in humans and animals (Bergsten et al., 2005). S pillus is constituted of subunits: sfaS subunit mediates $E$. coli interaction with intestinal and other epithelial cells. $s f a S$ gene is associated with human pyelonephritis, meningitis and sepsis (Féria et al., 2001). Haemolysin is a pore-forming cytotoxin that lyses erythrocytes, leukocytes, and endothelial and epithelial cells of mammals. The hly genes are frequently found in extraintestinal $E$. coli infections in humans and animals (Johnson et al., 1991). One of our isolates harbored the genes that encode papGI, $s f a$ and $h l y$. The identification of these virulence factors in a same isolate may be explained by the presence of a pathogenicity island (PAI), which enhances the infectivity of the microorganism. PAIs have been frequently found in E. coli responsible for human extraintestinal infections (Kurazono et al., 2000). In Brazil, genes that encode pap $G$ adhesins, as well as hly and $s f a$ genes, were found in E. coli strains isolated from pyometra, urinary tract infections, and feces of dogs (Siqueira et al., 2009). Free access of dogs to parks increases the risk of human infection with virulent $E$. coli. These animals may act as reservoirs, harboring pathogenic strains with virulence factors such as $p a p G, h l y$, and $s f a$ genes.

Iron is essential for bacterial metabolism. E. coli uses this ion for the transport and storage of both electrons and oxygen, and for DNA synthesis (Emödy et al., 2003). Growth of bacteria under restricted iron concentrations make them use successfully competitive mechanisms to obtain this ion from the host. Aerobactin is the most effective iron chelation system employed by $E$. coli for iron acquisition, mediated by $i u$ c genes types A, B, C and D (Griffiths, 1997). In humans, this virulence factor is intimately associated with urinary infections and septicemia (Torres et al., 2001). The iucD genes were found in only one isolate of our study. Currently, iuc genes have been found in dogs with pyometra (Coogan et al., 2004), urinary tract infections, and in dog feces in Brazil (Siqueira et al., 2009). Like other virulence factors, the presence of $i u c D$ gene in $E$. coli strains isolated from sand represents a risk to the population visiting these parks.

The presence of a self-agglutinating adhesin (saa) in E. coli has been previously described (Paton et al., 2001). Virulence of this adhesin to humans and domestic animals remains unclear. However, saa gene was found in $19.0 \%$ of E. coli strains obtained from the sand of parks in the current study. This result suggests that further studies should be carried out in order to investigate the role of this adhesin as an $E$. coli virulence factor.

E. coli have been phylogenetically classified in four groups named A, B1, B2 and D. E. coli strains belonging to groups $\mathrm{B} 2$ and $\mathrm{D}$ are commonly pathogenic for humans and animals, whereas A and B1 are less pathogenic (Clermont et al., 2000). Based on phylogenetic systematics, E. coli 
isolates obtained from the sand of parks were classified in A and B1 groups. Although these groups are predominantly related with non-pathogenic $E$. coli strains, these results indicate fecal contamination of the environment.

Toxocariasis is a cosmopolitan parasitic zoonosis. Toxocara spp. is one of the most common parasites of young dogs and cats. Eggs of the parasite are frequently shed in large amounts in the feces of companion animals. Toxocariasis in human occur by spread of the larvae, leading to different clinical forms of disease. Clinical manifestations involve serious neurological, ophthalmologic, pulmonary, and/or cutaneous signs (Acha and Szyfres, 2003). The presence of eggs of Toxocara spp. in the sand of parks have been reported in several countries (Dubná et al., 2007; Matsuo and Nakashio, 2005), including in Brazil(Santarém et al., 1998). Three parks had positive samples for eggs of this parasite. These results suggest environmental contamination by feces of companion animals and indicate risk of toxocariasis to humans that use these parks, particularly children.

Coronavirus infections in animals were reviewed elsewhere (Brandão et al., 2001). In Brazil, previous studies have identified Coronavirus in feces of cattle and dogs with and without diarrhea (Brandão et al., 2005, 2007). Identification of bovine Coronavirus in the sand from parks in Brazil is uncommon, although it also represents fecal contamination of the environment.

Rotavirus was detected in the feces of domestic animals (Rodriguez et al., 2004; Ruiz et al., 2009) and chickens (Villarreal et al., 2006) with and without diarrhea in Brazil. Likewise, different Salmonella spp. serotypes were detected in feces of livestock (Ribeiro et al., 2010), birds and chickens (Hofer et al., 1997) in this country. None of sand samples collected in our parks showed Rotavirus and Salmonella spp. In contrast, an epidemiological study involving human patients with salmonellosis in several European countries revealed that one the major risk factors for the disease was the access of children up to four years of age to the sand of parks (Doorduyn et al., 2006). These findings indicate that similar studies must be performed in other regions in Brazil in order to investigate the occurrence of Salmonella spp. and Rotavirus in the sand of parks. Despite the absence of Salmonella spp. and Rotavirus in the samples analyzed, these pathogens should be included in microbiological testing required to determine the sanitary conditions of the sand used in parks, as they may be shed in the feces of birds and domestic animals.

The identification of $R$. equi, E. coli EPEC, bovine Coronavirus, and Toxocara spp. are indicators of fecal contamination of the sand of the parks sampled. Contamination may have been caused by feces from domestic animals (Takai et al., 1996), birds (Prescott, 1991), or contaminated shoes of people who visit these places. Our results suggest the need to introduce control measures to prevent contamination of the sand by pathogens eliminated in animal feces.
In fact, the risks of the transmission of pathogens shed in animal feces in parks may reduce if access of domestic animals to these places is prevented, fecal material is daily removed from the sand, sand is periodically tested for sanitary quality and replaced with material of known origin, and people are continuously educated on hygiene habits before using parks.

The presence of R. equi, E. coli EPEC, Toxocara spp. and bovine Coronavirus identified in parks studied indicates environmental contamination by microorganisms found in feces of domestic animals, birds, and/or contaminated shoes of people. These results represent a risk for the transmission of pathogens with zoonotic potential to humans in these places, particularly to children.

\section{Acknowledgments}

This work was supported by FAPESP - Fundação de Amparo à Pesquisa do Estado de São Paulo, Brazil (2007/57781-3)

\section{References}

Acha PN, Szyfres B (2003) Zoonoses y Enfermidades Transmisibles Comunes al Hombre y los Animales. $3^{\text {rd }}$ ed., Organización Panamericana de la Salud, Washington., vol. 1, 398 pp.

Akashi H, Inaba Y, Miura Y, Tokuhisha S, Sato K, Satoda K (1980) Properties of a coronavirus isolated from a cow with epizootic diarrhea. Vet Microbiol 5:265-276.

Andrews WH, June GA, Sherrod PS, Hammack TS, Amaguana RM (1998) Salmonella. In: Andrews, W.H.; June, G.A.; Sherrod, P.S.; Hammack, T.S.; Amaguana, R.M. (eds). Bacteriological Analytical Manual. Food and Drug Administration, Gaithersburg, pp 5001-5020.

Aranda KRS, Fagundes-Neto U, Scaletsky ICA (2004) Evaluation of Multiplex PCRs for diagnosis of infection wit diarrheagenic Escherichia coli and Shighella spp. J Clin Microbiol 42:5849-5853.

Bergsten G, Wullt B, Svanborg C (2005) Escherichia coli, fimbriae, bacterial persistence and host response induction in the human urinary tract. Int J Med Microbiol 295:487-502.

Blanco M, Blanco JE, Blanco J, Alonso MP, Balsalobre C, Mourino M, Madrid C, Juárez A (1996) Polymerase chain reaction for detection of Escherichia coli strains producing cytotoxic necrotizing factor type 1 and type 2 (CNF1 and CNF2). J Microbiol Methods 26:95-101.

Blanco M, Blanco JE, Alonso MP, Mora A, Balsalobre C, Munoa F, Juárez A, Blanco J (1997) Detection of pap, sfa and afa adhesin-encoding operons in uropathogenic Escherichia coli strains: relationship with expression of adhesions and production of toxins. Res Microbiol 148:745-755.

Brandão PE, Gregori F, Villarreal LYB, Rosales CAR, Soares RM, Jerez JA (2005) A nested polymerase chain reaction to bovine coronavirus diagnosis. Virus Rev Res 10:45-49.

Brandão PE, Gregori F, Heinemann MB, Lima CHA, Rosales CAR, Ruiz VLA (2001) Animal coronaviruses. Virus Rev Res 6:7-13.

Brandão PE, Gregori F, Sforsin AJ, Villarreal LYB, Jerez JA (2007) Winter dysentery in dairy cows associated with Bo- 
vine coronavirus (BCoV). Arq Bras Med Vet Zootec 59:1074-1076

Clermont O, Bonacorsi S, Bingen E (2000) Rapid and Simple Determination of the Escherichia coli Phylogenetic Group. Appl Environ Microbiol 66:4555-4558.

Coogan JÁ, Oliveira CM, Faustino M, Moreno AM, Von Sydow AC, Melville PA, Benites N.R. (2004) Estudo microbiológico de conteúdo intra-uterino de cadelas com piometra e pesquisa de fatores de virulência em cepas de Escherichia coli. Arq Inst Biol. São Paulo, 71:513-515.

Doorduyn Y, Van Den Brandhof WE, Van Duynhoven YT, Wannet WJ, Van Pelt W (2006) Risk factors for Salmonella Enteritidis e Typhimurium (DT104 and DT104) infections in the Netherlands: predominant roles for raw eggs in Enteritidis and sandboxes in Typhimurium infections. Epidemiol Infect 134:617-626.

Dubná S, Langrová I, Jankovská I, Vadlejch J, Pekár S, Nápravník J, Fechtnera J (2007) Contamination of soil with Toxocara eggs in urban (Prague) and rural areas in the Czech Republic. Vet Parasitol 144:81-86.

Emödy L, Kerényi M, Nagy G (2003) Virulence factors of uropathogenic Escherichia coli. Int J Antimicrob Agents 22:2933.

Farias MR, Takai S, Ribeiro MG, Fabris V (2007) Cutaneous pyogranuloma in a cat caused by virulent Rhodococcus equi containing an $87 \mathrm{~kb}$ type I plasmid. Aust Vet J 85:29-31.

Féria C, Machado J, Correia JD, Gonçalves J, Gaastra W (2001) Distribution of papG alleles among uropathogenic Escherichia coli isolated from different species. FEMS Microbiol Lett 202:205-208.

Griffiths E (1997) Iron and the virulence of Escherichia coli. In: Sussman, M. (Ed.). Escherichia coli Mechanisms of Virulence. Cambridge University Press, Cambridge, pp 331-371.

Herring AJ, Inglis NF, Ojeh CK, Snodgrass DR, Menzies JD (1982) Rapid diagnosis of rotavirus infection by direct detection of viral nucleic acid in silver-stained poliacrylamide gels. J Clin Microbiol 16:473-477.

Hofer E, Silva Filho SJ, Reis EMF (1997) Prevalência de Sorovares de Salmonella isolados de aves no Brasil. Pesq Vet Bras 17:55-62.

Johnson JR (1991) Virulence factors in Escherichia coli urinary tract infection. Clin Microbiol Rev 4:80-128.

Kaper JB, Nataro JP, Mobley HLT (2004) Pathogenic Escherichia coli. Nature Reviews 2:23-140.

Karkkainen UM, Kauppinen J, Ikaheimo R, Katila ML, Siitonen A (1998) Rapid and specific detection of three different $G$ adhesin classes of P-fimbriae in uropathogenic Escherichia coli by polymerase chain reaction. J Microbiol Methods 34:23-29.

Kuehn MJ, Jacob-Dubuisson F, Dodson K, Slonim L, Striker R, Hultgren SJ (1994) Genetic, biochemical, and structural studies of biogenesis of adhesive pili in bacteria. Methods Enzymol 236:282-306.

Kurazono H, Yamamoto S, Nakano M, Fair GB, Terai A, Chaicumpa W, Hayashi H (2000) Characterization of a putative virulence island in the chromosome of uropathogenic Escherichia coli possessing a gene encoding a uropathogenicspecific protein. Microbial Pathogen 28:183-189.

Matsuo J, Nakashio S (2005) Prevalence of fecal contamination in sandpits in public parks in Sapporo City, Japan. Vet Parasitol 128:115-119.
Paton, AW, Srimatone P, Woodrow MC, Paton JC (2001) Characterization of Saa, a novel autoagglutinating adhesin produced by locus of enterocyte effacement-negative Shiga toxigenic Escherichia coli strains that are virulent for humans. Infect Immun 69:6999-7009.

Popoff MY, Le Minor L (1992) Formules antigéniques des sérovars de Salmonella. Centre Collaborateur OMS de réference et de recherches pour les Salmonella.

Prescott JF (1991) Rhodococcus equi: an animal and human pathogen. Clin Microbiol Rev 4:20-34.

Quinn PJ, Carter ME, Markey BM, Carter GR (1994) Clinical Veterinary Microbiology. Wolfe, London, $648 \mathrm{pp}$.

Ribeiro MG, Takai S, Vargas AC, Mattos-Guaraldi AL, Camello TCF, Ohno R, Okano H, Silva AV (2011) Identification of virulence associated plasmids in Rhodococcus equi in humans with and without acquired immunodeficiency syndrome in Brazil. Am J Trop Med Hyg 85:510-513.

Ribeiro MG, Seki I, Yasuoka K, Kakuda T, Sasaki Y, Tsubaki S, Takai S (2005) Molecular epidemiology of virulent Rhodococcus equi from foals in Brazil: virulence plasmids of 85-kb type I, 87-kb type I, and a new variant, 87-kb type III. Comp Immunol Microbiol Infect Dis 28:53-61.

Ribeiro MG, Fernandes MC, Paes AC, Siqueira AK, Pinto JPAN, Borges AS (2010) Caracterização de sorotipos em linhagens do gênero Salmonella isoladas de diferentes afecções em animais domésticos. Pesq Vet Bras 30:155-160.

Rodrigues J, Thomazini CM, Lopes CAM, Dantas LO (2004) Concurrent infection in a dog and colonization in a child with a human enterophatogenic Escherichia coli clone. J Clin Microbiol 42:1388-1389.

Rodriguez CAR, Brandão PE, Ferreira F, Gregori F, Buzinaro MG, Jerez JA (2004) Improved animal rotavirus isolation in MA-104 cells using different trypsin concentrations. Arq Inst Biol. São Paulo, 71:437-441.

Ruiz VLA, Brandão PE, Gregori F, Rodriguez CAR, Souza SLP, Jerez JA (2009) Isolation of rotavirus from asymptomatic dogs in Brazil. Arq Bras Med Vet Zoot 61:996-999.

Santarém VA, Sartor IF, Bergamo FMM (1998) Contaminação por ovos de Toxocara spp em parques e praças públicas de Botucatu, SP, Brasil. Rev Soc Bras Med Trop 31:529-532.

Schmidt H, Knop C, Franke S, Aleksic S, Heesemann J, Karch H (1995) Development of PCR for screening of enteroaggregative Escherichia coli. J Clin Microbiol 33:701-705.

Siqueira AK, Ribeiro MG, Leite DS, Tiba MR, Moura C, Lopes MD, Prestes NC, Salerno T, Silva AV (2009) Virulence factors in Escherichia coli strains isolated from urinary tract infection and pyometra cases and from feces of dogs. Res Vet Sci 86:206-210.

Takai S, Sekizaki T, Ozawa T, Sugawara T, Watanabe W, Tsubaki S (1991) Association between a large plasmid and 15to 17-kilodalton antigens in virulent Rhodococcus equi. Infect Immun 59:4056-4060.

Takai S (1997) Epidemiology of Rhodococcus equi infections: A review. Vet Microbiol 56:167-176.

Takai S, Fukunaga N, Ochiai S, Sakai T, Sasaki Y, Tsubaki S (1996) Isolation of virulent and intermediately virulent Rhodococcus equi from soil and sand on parks and yards in Japan. J Vet Med Sci 58:669-672.

Takai S, Tharavichitkul P, Takarn P, Khantawa B, Tamura M, Tsukamoto A, Takayama S, Yamatoda N, Kimura A, Sasaki Y, Kakuda T, Tsubaki S, Maneekarn N, Sirisanthana T, 
Kirikae T (2003) Molecular epidemiology of Rhodococcus equi of intermediate virulence isolated from patients with and without Acquired Immune Deficiency Syndrome in Ching Mai, Thailand. J Infect Dis 188:1717-1723.

Torres AG, Redford P, Welch RA, Payne SM (2001) TonBdependent systems of uropathogenic Escherichia coli: aerobactin and heme transport and TonB are required for virulence in the mouse. Infect Immun 69:6179-6185.

Triola MF (2005) Introdução à Estatística. $9^{\text {th }}$ ed. LTC, Rio de Janeiro, $682 \mathrm{pp}$.
Villarreal LYB, Uliana G, Valenzuella C, Chacón JLV, Saindenberg ABS, Sanches AA, Brandão PE, Jerez JA, Ferreira AJP (2006) Rotavirus detection and isolation from chicken with and without symptoms. Braz J Poultry Dis 8:187-191.

Yamamoto S, Terai A, Yuri K, Kurazono H, Takeda Y, Yoshida O (1995) Detection of urovirulence factors in Escherichia coli by multiplex polymerase chain reaction. FEMS Immunol Med Microbiol 12:85-90.

All the content of the journal, except where otherwise noted, is licensed under a Creative Commons License CC BY-NC. 